\title{
MEMAKNAI HADITS QUL KHAIRAN AULIYASHMUT DALAM KONTEKS PENDIDIKAN ISLAM DI ERA REVOLUSI INDUSTRI 4.0
}

\author{
Setyoadi Purwanto \\ E-mail: adikitana06@gmail.com \\ Mahasiswa Doktoral Pendidikan Agama Islam \\ Universitas Islam Negeri Sunan Kalijaga Yogyakarta
}

Abstrak

Peradaban manusia bermula dari kata-kata. Kata-kata yang baik akan membawa pemikiran, sikap, dan tindakan yang baik pula. Dalam pendidikan Islam kata-kata terbaik itu bermula dari A1 Qur'an dan Hadits Nabi saw. Sebagai tuntunan paripurna petunjuk yang disampaikan Nabi dalam teks hadits berlaku sepanjang masa. Di era Revolusi Industri yang ditandai dengan proses digitalisasi segala aspek kehidupan termasuk budaya komunikasinya, kita tetap menemukan mutiara dari pesanpesan nabi dalam Hadits. Penelitian ini mencoba mengkontruksi makna hadits Qul khairan auliyasmuth dalam konteks Pendidikan Islam di era Revolusi Industri 4.0. Penelitian ini adalah penelitian literal dengan mengkaji sumber utama Al Qur'an dan hadits yang dikomparasikan dengan pandangan para pakar komunikasi barat dan Islam bertujuan menemukan formulasi komunikasi terbaik dalam konteks pendidikan Islam era Revolusi Industri 4.0. Upaya membangun komunikasi digital tanpa meninggalkan etika moral dan tanggung jawab dalam berkomunikasi, sehingga komunikasi tidak sekedar efektif dan efisien namun juga benar dan kontruktif menjadi sorotan utama dalam tulisan ini.

\section{Kata Kunci: Qul Khairan, Pendidikan Islam, Era Revolusi Industri 4.0.}

\section{Abstract}

Human civilization stems from words. Good words will bring good thoughts, attitudes, and actions. In Islamic education the best words start from the Qur'an and the Hadith of the Prophet. As a complete guide the instructions conveyed by the Prophet in the hadith texts apply throughout the ages. In the era of the Industrial Revolution which was marked by the process of digitizing all aspects of life including its communication culture, we still found the pearl of the prophet's messages in the Hadith. This study tries to construct the meaning of the hadith of Qul khairan auliyasmuth in the context of Islamic Education in the era of the Industrial 
Setyoadi Purwanto : Memaknai Hadits Qul Khairan Auliyashmut dalam Konteks Pendidikan Islam di Era Revolusi Industri 4.0

Revolution 4.0. This research is a literal research by examining the main sources of the Qur'an and hadith compared with the views of western and Islamic communication experts aimed at finding the best formulation of communication in the context of the Industrial Revolution 4.0 of Islamic education. Efforts to build digital communication without leaving moral ethics and responsibility in communication, so that communication is not only effective and efficient but also true and constructive in the main focus of this paper. Human civilization stems from words. Good words will bring good thoughts, attitudes, and actions. In Islamic education the best words start from the Qur'an and the Hadith of the Prophet. As a complete guide the instructions conveyed by the Prophet in the hadith texts apply throughout the ages. In the era of the Industrial Revolution which was marked by the process of digitizing all aspects of life including its communication culture, we still found the pearl of the prophet's messages in the Hadith. This study tries to construct the meaning of the hadith of Qul khairan auliyasmuth in the context of Islamic Education in the era of the Industrial Revolution 4.0. This research is a literal research by examining the main sources of the Qur'an and hadith compared with the views of western and Islamic communication experts aimed at finding the best formulation of communication in the context of the Industrial Revolution 4.0 of Islamic education. Efforts to build digital communication without leaving moral ethics and responsibility in communication, so that communication is not only effective and efficient but also true and constructive in the main focus of this paper.

\section{Keywords: Qul Khairan, Islamic Education, Era of Industrial Revolution 4.0}

\section{A. PENDAhUluan}

Dunia saat ini tengah memasuki era baru yang disebut Revolusi Industri 4.0. Sebuah era yang ditandai perubahan digitalisasi di segala bidang kehidupan. Inovasi dan persaingan global menjadi tuntutan dan kebutuhan yang tak terelakkan lagi. Antusiasme kalangan mileneal menghadapi era baru ini disisi lain memunculkan kekhawatiran yang besar di kalangan pendidik dan orangtua. Skills penguasaan teknologi yang menjadi ciri dan kelebihan generasi milenial tanpa diimbangi 
Setyoadi Purwanto : Memaknai Hadits Qul Khairan Auliyashmut dalam Konteks Pendidikan Islam di Era Revolusi Industri 4.0

dasar moral etika yang kokoh dikhawatirkan akan menjadi bumerang hancurnya karakter positif dalam tumbuh kembang anak-anak.

Setiap anak terlahir fitrah dengan membawa segenap potensi Ilahiah. Dalam rentang perjalanan dan proses tumbuhkembangnya anak mengalami banyak penyimpangan tidak seperti yang diharapkan. Penyimpangan ini tak jarang dipicu sendiri oleh sikap dan pola asuh orangtua kepada anak. Sebagaimana sabda Nabi Shallallahu'alaihi Wasallam:

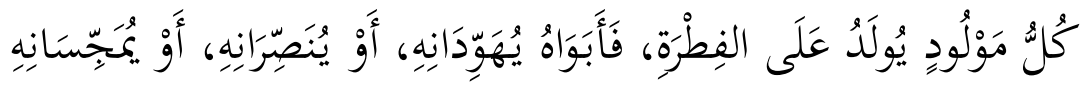

Artinya:

"Setiap anak manusia yang lahir, mereka lahir dalam keadaan fitrah. Orang tuanya lah yang menjadikannya Yahudi atau Nasrani” (HR. Bukhari-Muslim)

Salah satu sikap dan bentuk pola asuh orangtua terhadap anak yang memicu karakter apatis, emosional, pemalu, sulit bergaul dan bahkan menaruh dendam adalah pola asuh rejection (penolakan) atau yang dikenal pula dengan authoritarian (otoriter). Orangtua yang menerapkan pola asuh ini cenderung bersikap keras, kata-katanya tajam dan menyakitkan hati, terlalu disiplin dan mudah menghukum.

Kasus pembunuhan tiga orang balita di Bandung yang sempat menggemparkan dunia pendidikan kita di tahun 2006 lalu menjadi pelajaran dan bahan kajian serius khususnya bagi guru dan orangtua di era milenia ini. Bukan saja karena pembunuhan itu dilakukan sendiri oleh Bu Anik, yang merupakan ibu kandung korban yang terpelajar dan sangat menyayangi anaknya, namun jauh dibalik kasus itu ternyata bu Anik merasa menjadi korban kata-kata orangtuanya sejak masa 
Setyoadi Purwanto : Memaknai Hadits Qul Khairan Auliyashmut dalam Konteks Pendidikan Islam di Era Revolusi Industri 4.0

balita. Ironisnya kasus-kasus seperti ini tidaklah berhenti pada satu kasus Ibu Anik saja, tapi telah berulang-ulang terjadi di negeri ini dan berbagai belahan dunia lainnya.

Terkait latar belakang tersebut, makalah ini bermaksud mengkaji Ekspresi kalimat dalam kontek pendidikan anak-anak dan pengaruhnya terhadap pembentukan karakter mereka di era Revolusi Industri 4.0. Rujukan utama yang akan dikaji dalam makalah ini adalah hadits Nabi tentang berbicara yang baik atau diam. Dengan harapan akan ada perubahan dalam tatanan masyarakat utamanya pola asuh dan sikap mendidik yang lebih baik dari setiap orangtua dan guru yang bersumber dari sunah Nabi. Sebab, tiada sunnah tanpa pemahaman yang benar, sebagaimana tiada ilmu dan peradaban Islami tanpa sunnah Nabi saw.

\section{B. PEMBahasan}

1. Dua Pilihan Utama, Berkata Yang Baik Atau Diam

Berkata baik menjadi penanda baiknya akhlaq pemiliknya. Ada peribahasa jawa yang sangat terkenal, Ajining diri gumantung saka lathi yang bermakna kemuliaan seseorang ditentukan oleh kata-kata yang terlahir dari lisannya. Orang-orang Melayu pun memiliki kata peribahasa yang tak kalah hebat, Mulutmu harimaumu yang memiliki makna serupa, keselamatan seseorang tergantung mulut atau lisannya. Di kalangan umat Islam, kita pun mengenal ada Hadits Nabi yang sangat masyhur berkait hal ini. Hadits dari sahabat Abu Hurairah ini berbunyi:

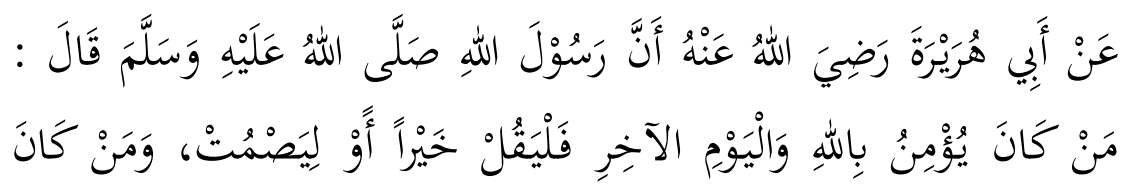




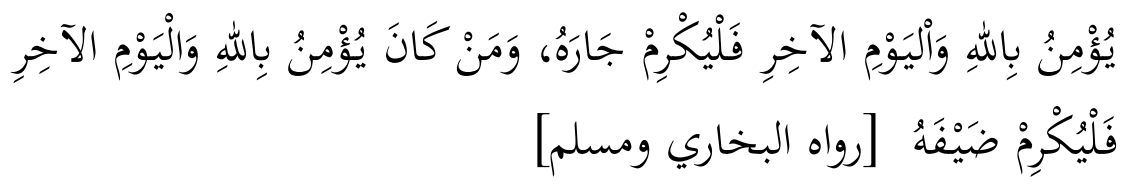

Artinya:

"Dari Abu Hurairah radhiallahuanhu, sesungguhnya Rasulullah Shallallahu'alaihi wasallam bersabda: Barangsiapa yang beriman kepada Allah dan hari akhir hendaklah dia berkata baik atau diam, siapa yang beriman kepada Allah dan hari akhir hendaklah dia menghormati tetangganya dan barangsiapa yang beriman kepada Allah dan hari akhir maka hendaklah dia memuliakan tamunya." (Riwayat Bukhori dan Muslim)

Pesan di bagian awal hadits Nabi tersebut bukanlah hal yang ringan dan main-main. Rasulullah melalui hadits ini menunjukkan adanya korelasi yang sangat kuat antara lurusnya aqidah seseorang dengan kemampuan berbicara yang baik. Seolah hanya ada dua pilihan bagi orang-orang yang beriman dalam hal berbicara. Yakni bicara yang baik, atau diam. Benarkah demikian? Apakah banyak bicara seperti yang diisyaratkan dalam hadits Nabi tersebut masuk kategori mutlak diharamkan? Lalu seperti apa kriteria berkata yang baik sebagaimana yang diinginkan Nabi dalam hadits tersebut? Sungguh ini adalah suatu hal yang seakan menakutkan. Lebih-lebih dalam perbincangan publik di era informasi digital yang sangat cepat ini. Sebuah kata-kata bisa menyebar sangat cepat dalam ruang dan waktu yang nyaris tak berbatas.

2. Perkataan Yang Baik Dalam Al Qur'an

a. Qoulan Sadida

Dalam konteks pendidikan anak, Al Quran membahasakan perkataan yang baik ini dengan istilah 
Setyoadi Purwanto : Memaknai Hadits Qul Khairan Auliyashmut dalam Konteks Pendidikan Islam di Era Revolusi Industri 4.0

Qoulan sadida. Sebagaimana firman Allah SWT di dalam Al Quran surat An Nisa' [4] ayat 9:

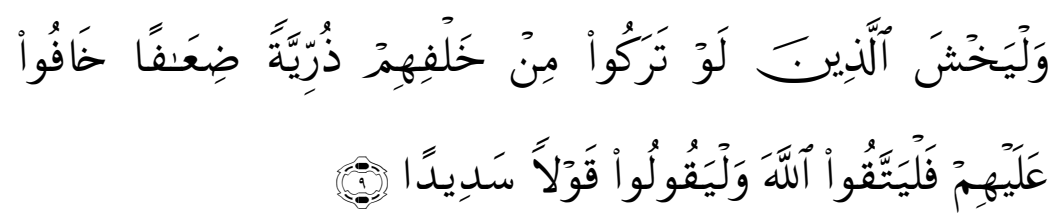

Artinya:

"Dan hendaklah orang-orang takut kepada Allah, bila seandainya mereka meninggalkan anak-anaknya, yang dalam keadaan lemah, yang mereka khawatirkan terhadap (kesejahteraan) mereka. Oleh sebab itu, hendaklah mereka bertakwa kepada Allah dan mengucapkan perkataan yang benar.” (QS. An-Nisa': 9)

Muhammad Marmaduke Pickthall sebagaimana dikutip Fauzil Adzim menyatakan bahwa qoulan sadidan mempunyai pengertian apa adanya dan tidak berbelitbelit. Secara sederhana qoulan sadidan berarti perkataan yang benar sekaligus tidak menutupi kebenaran. Muhammad Sayyid Thanthawi berpendapat bahwa ayat di atas ditujukan kepada semua pihak, siapapun, karena semua diperintahkan untuk berlaku adil, berucap yang benar dan tepat, dan semua khawatir akan mengalami apa yang digambarkan di atas.

Kata (سََِيْدًا ) sadidan, terdiri dari huruf w dan د yang menurut pakar bahasa Ibn Faris menunjuk kepada makna meruntuhkan sesuatu kemudian memperbaikinya. Ia juga berarti istiqamah konsisten. Kata ini juga digunakan untuk menunjuk kepada sasaran. Seorang yang menyampaikan sesuatu ucapan yang benar dan mengena tepat pada sasarannya, dilukiskan dengan kata ini. Dengan demikian kata سَديْدَا dalam ayat di atas, tidak 
Setyoadi Purwanto : Memaknai Hadits Qul Khairan Auliyashmut dalam Konteks Pendidikan Islam di Era Revolusi Industri 4.0

sekedar berarti benar, sebagaimana terjemahan sementara penerjemah, tetapi ia juga harus berarti tepat sasaran.

b. Qoulan Layyina

Selain kata Qoulan sadidan, dalam Al Quran juga ditemukan kata qoulan layyina, qoulan kariima, qoulan ma'rufa, dan qoulan tsaqila. Kata qoulan layyina dapat kita temukan dalam Al Quran surat Toha ayat 44 sebagai berikut:

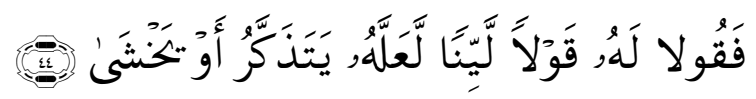

Artinya:

"Maka bicaralah kamu berdua kepada (Fir'aun) dengan kata-kata yang lemah lembut, mudah-mudahan dia sadar atau takut." (QS. Thaha: 44)

Menurut al-Maraghi ayat ini berbicara dalam konteks pembicaraan nabi Musa As. ketika menghadap Fir'aun. Allah mengajarkan kepadanya agar berkata lemah lembut dengan harapan Firaun tertarik dan tersentuh hatinya sehingga dia dapat menerima dakwahnya dengan baik. Sementara Ibnu Katsir menyebut qaulan layyina sebagai ucapan yang lemah lembut. Senada dengan itu, Assiddiqi memaknai qaulan layyina sebagai perkataan yang lemah lembut yang didalamnya terdapat harapan agar orang yang diajak bicara menjadi teringat pada kewajibannya atau takut meninggalkan kewajibannya. 
Setyoadi Purwanto : Memaknai Hadits Qul Khairan Auliyashmut dalam Konteks Pendidikan Islam di Era Revolusi Industri 4.0

\section{c. Qoulan Kariima}

Dalam al-Quran ungkapan qaulan kariima disebut sebanyak satu kali yaitu pada surat al-Isra ayat 23:

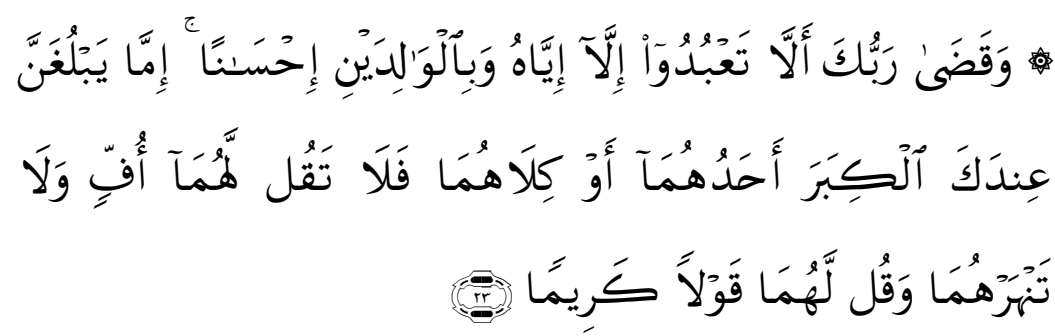

Artinya:

"Dan tuhanmu telah memerintahkan agar kamu tidak menyembah selain Dia dan hendaklah berbuat baik kepada ibu bapak. Jika salah seorang diantara keduanya atau kedua-duanya sampai berusia lanjut dalam pemeliharaanmu, maka sekali-kali janganlah engkau mengatakan kepada keduanya perkataan "Ah" dan janganlah engkau membentak keduanya, dan ucapkanlah kepada keduanya perkataan yang baik." (QS al-Isra: 23)

Secara leksikal ungkapan tersebut bermakna perkataan yang mulia. Al-Maraghi menafsirkan ungkapan qaulan karima dengan makna yang merujuk pada ucapan Ibn Musayyab, yaitu ucapan seorang budak yang bersalah di hadapan majikannya yang galak. Ibnu Katsir menjelaskan makna qaulan karima dengan arti lembut, baik, dan sopan disertai tata krama, penghormatan dan pengagungan. Dengan memperhatikan penjelasan para mufassir di atas, dapat disimpulkan bahwa ungkapan qaulan karima memiliki pengertian mulia, penghormatan, pengagungan, dan penghargaan. Ucapan yang bermakna qaulan karima berarti ucapan yang lembut berisi pemuliaan, penghargaan, pengagungan, dan penghormatan kepada orang yang diajak bicara. 
Setyoadi Purwanto : Memaknai Hadits Qul Khairan Auliyashmut dalam Konteks Pendidikan Islam di Era Revolusi Industri 4.0

Sebaliknya ucapan yang menghinakan dan merendahkan orang lain merupakan ucapan yang tidak santun.

d. Qoulan Ma'ruufa

Kata ma'ruf bermakna diketahui, dikenal, baik, ramah. Menurut Qurays Shihab secara leksikal kata ma'ruf bermakna baik dan diterima oleh nilai-nilai yang berlaku dalam masyarakat. Ucapan yang baik adalah ucapan yang diterima sebagai sesuatu yang baik dalam pandangan masyarakat lingkungan penutur.

Ungkapan Qoulan Ma'ruufa dalam al-Quran terdapat pada lima tempat yaitu Al-Baqarah: 235 dan 263, an-Nisa : 5 dan 8 dan pada surat Al-Ahzab : 32. Redaksi dalam surat Al-Baqarah 263 dapat kita simak sebagai berikut:

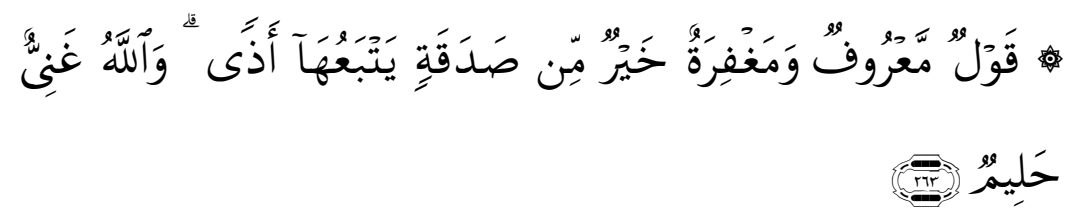

Artinya:

"Perkataan yang baik dan pemberian maaf lebih baik daripada sedekah yang diiringi tindakan yang menyakiti. Allah Maha Kaya, Maha Penyantun.” (QS Al-Baqarah: 263)

Menurut Qurays Shihab Perkataan yang menentramkan hati dan menutup-nutupi aib si fakir dengan tidak menceritakannya kepada orang lain, lebih baik dari sedekah yang disertai perkataan dan perbuatan yang menyakitkan. Allah tidak butuh kepada pemberian yang disertai sikap menyakiti. Dia akan memberikan rezeki yang baik kepada orang-orang fakir. Dan Dia tidak akan menyegerakan hukuman-Nya terhadap orang yang 
Setyoadi Purwanto : Memaknai Hadits Qul Khairan Auliyashmut dalam Konteks Pendidikan Islam di Era Revolusi Industri 4.0

tidak bersedekah dengan harapan orang itu akan berubah sikapnya kemudian. Sementara Hamka memaknai qaulan ma'rufa sebagai ucapan bahasa yang sopan santun, halus, dan penuh penghargaan. Ketika memaknai ungkapan tersebut yang terdapat pada surat al-Isra ayat 23 yang berkaitan dengan etika berkomunikasi dengan orang tua beliau mengartikan sebagai ucapan yang khidmat, dasar budi kepada orang tua. Assidiqi menyebutnya sebagai perkataan yang baik, yaitu katakata yang tidak membuat orang lain atau dirinya merasa malu. Qaulan ma'rufa adalah perkataan yang baik, benar, menyenangkan dan disampaikan dengan tidak diikuti oleh celaan dan cacian.

Dengan memperhatikan pendapat para mufassir di atas dapat ditarik kesimpulan bahwa qaulan ma'rufa mengandung arti perkataan yang baik, yaitu perkataan yang sopan, halus, indah, benar, penuh penghargaan, dan menyenangkan, serta sesuai dengan hukum dan logika. Dalam pengertian di atas tampak bahwa perkataan yang baik adalah perkataan yang bahasanya dapat difahami oleh orang yang diajak bicara dan diucapkan dengan pengungkapan yang sesuai dengan norma dan diarahkan kepada orang (objek) yang tepat.

e. Qoulan Baliigha

Secara literal makna baliigha berarti yang fasih (lihat al-Munawwir 107). Ungkapan qaulan baligha dalam Al-Quran disebut sebanyak satu kali yaitu pada surat AnNisa ayat 63: 


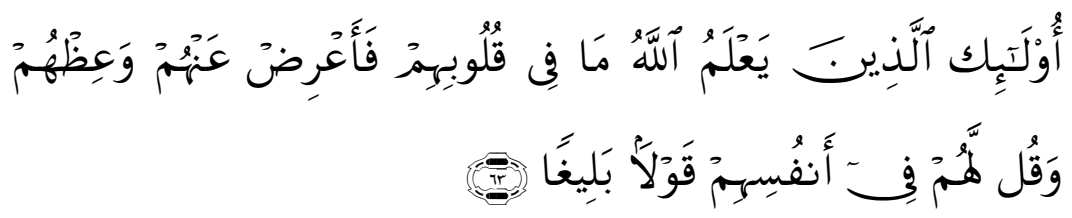

Artinya:

"Mereka itu adalah orang-orang yang (sesumgguhmya) allah mengetahui apa yang ada dalam hatinya. Karena itu berpalinglah kamu dari mereka, dan berilah mereka nasihat, dan katakanlah kepada mereka perkataan yang membekas pada jiwanya.” (QS An-Nisa: 63)

Ungkapan tersebut diartikan sebagai pembicaraan yang fasih, jelas maknanya, terang, serta tepat dalam mengungkapkan apa yang dikehendakinya.

Buya Hamka menyebutkan bahwa ungkapan qaulan baligha bermakna ucapan yang sampai pada lubuk hati orang yang diajak bicara, yaitu kata-kata yang fashahat dan balaghah (fasih dan tepat); kata-kata yang membekas pada hati sanubari. Kata-kata seperti ini tentunya keluar dari lubuk hati sanubari orang yang mengucapkannya. Sementara al-Buruswi memaknai qaulan baligha dari segi cara mengungkapkannya. Lebih lanjut al-Maraghi mengaitkan qaulan baligha dengan arti tabligh sebagai salah satu sifat Rasul (Tabligh dan baligh berasal dari akar kata yang sama yaitu balagha), yaitu nabi Muhammad diberi tugas untuk menyampaikan peringatan kepada umatnya dengan perkataan yang menyentuh hati mereka. Senada dengan itu, Katsir menyatakan makna kalimat ini, yaitu menasihati dengan ungkapan yang menyentuh sehingga mereka berhenti dari perbuatan salah yang selama ini mereka lakukan. Dari segi lain Asidiqi memaknai qaulan baligha dari segi gaya 
Setyoadi Purwanto : Memaknai Hadits Qul Khairan Auliyashmut dalam Konteks Pendidikan Islam di Era Revolusi Industri 4.0

pengungkapan, yaitu perkataan yang membuat orang lain terkesan atau mengesankan orang yang diajak bicara.

f. Qoulan Maysuura

Ungkapan kata qoulan maysuura terdapat dalam surat Al-Isra' ayat 28 sebagai berikut:

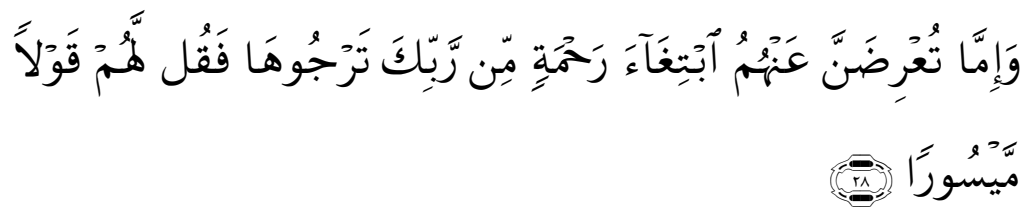

Artinya:

"Dan jika kamu berpaling dari mereka untuk memperoleh rahmat dari Tuhanmu yang kamu harapkan, maka katakanlah kepada mereka ucapan yang pantas.”

Menurut Jalaludin Rakhmat, qoulan maysuura lebih dekat dengan makna kalimat atau perkataan yang menyenangkan, gampang, mudah dan ringan. Pada saat berkomunikasi, seseorang tidak saja menyampaikan konten kalimat namun juga membangun hubungan sosial satu dengan lainnya. Konten yang sama jika dikomunikasikan bisa menimbulkan permusuhan namun bisa pula merajut persaudaraan. Maka qoulan maysuura membawa prinsip bahwa komunikasi dalam Islam haruslah membawa spirit perdamaian dan persaudaraan. Tujuannya adalah mendekatkan diri pada Tuhan dan sesamanya.

3. Makna Qul Khairan Auliyashmut dalam Hadits Nabi

Hadits yang dimaksud dalam kajian makalah ini adalah sebagai berikut, 
Setyoadi Purwanto : Memaknai Hadits Qul Khairan Auliyashmut dalam Konteks Pendidikan Islam di Era Revolusi Industri 4.0

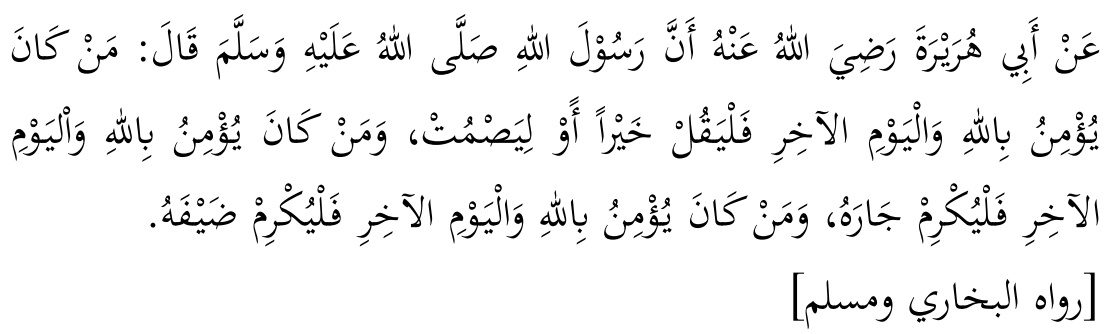

Artinya:

"Dari Abu Huroiroh Rodhiyallahu 'anhu bahwa Rosulullah Shollallahu 'alaihi wa sallam bersabda: " Barang siapa beriman kepada Allah dan Hari Akhir maka hendaknya berbicara baik atau diam, barang siapa beriman kepada Allah dan Hari Akhir maka hendaknya ia menghormati tetangganya, dan barang siapa beriman kepada Allah dan Hari Akhir maka hendaknya ia menghormati tamunya." (HR Bukhari dan Muslim)

a. Bicara baik atau diam adalah ciri seorang muslim

Hal ini sebagaimana disampaikan Rasulullah dalam hadits sebagai berikut, diriwayatkan dari Abdullah bin Amr ra. Bahwa Nabi saw. Pernah bersabda, "Seorang muslim adalah orang yang tidak merugikan Muslim lainnya dengan lidah maupun kedua tangannya. Dan seorang Muhajir adalah mereka yang meninggalkan semua larangan Allah.”

Bahkan dalam hadits lainnya, Rasulullah menggambarkan akhlaq bicara baik atau diam bukan saja sebagai ciri seorang muslim biasa, namun seorang Muslim yang terbaik. Diriwayatkan dari Abu Musa r.a. ada beberapa orang yang bertanya kepada Rasulullah saw, “Siapakah muslim yang terbaik itu?" Rasulullah saw., "Muslim terbaik adalah Muslim yang tidak merugikan Muslim lainnya dengan lidah maupun kedua tangannya." 
Setyoadi Purwanto : Memaknai Hadits Qul Khairan Auliyashmut dalam Konteks Pendidikan Islam di Era Revolusi Industri 4.0

b. Bicara baik adalah keberuntungan dan diam adalah keselamatan

Kebiasaan berkata baik dan benar bukan saja membawa kita kepada keberuntungan biasa, namun ia akan membawa kita kepada keberuntungan terbesar berupa surga.

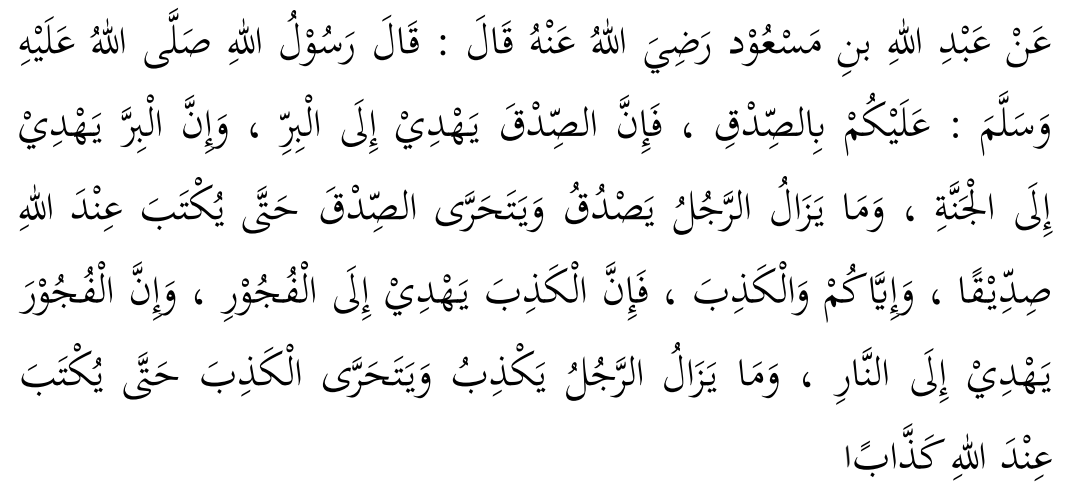

Artinya:

"Dari 'Abdullâh bin Mas'ûd Radhiyallahu anhu, ia berkata: "Rasûlullâh Shallallahu 'alaihi wa sallam bersabda, 'Hendaklah kalian selalu berlaku jujur, karena kejujuran membawa kepada kebaikan, dan kebaikan mengantarkan seseorang ke Surga. Dan apabila seorang selalu berlaku jujur dan tetap memilih jujur, maka akan dicatat di sisi Allâh sebagai orang yang jujur. Dan jauhilah oleh kalian berbuat dusta, karena dusta membawa seseorang kepada kejahatan, dan kejahatan mengantarkan seseorang ke Neraka. Dan jika seseorang senantiasa berdusta dan memilih kedustaan maka akan dicatat di sisi Allâh sebagai pendusta (pembohong)."

Hadits di atas diperkuat oleh hadits lainnya, sebagaimana diriwayatkan Ibnu Mubarak Rasulullah saw. Menyatakan; “(Semoga) Allah SWT. Menyayangi seseorang yang berkata baik, sehingga dia mendapatkan keberuntungan atau diam sehingga dia selamat." (Hadits 
Setyoadi Purwanto : Memaknai Hadits Qul Khairan Auliyashmut dalam Konteks Pendidikan Islam di Era Revolusi Industri 4.0

riwayat Ibnu Mubarak dalam az Zuhdu, secara mursal dengan sanad Hasan)

Hadits tersebut diatas diriwayatkan dalam berbagai sanad. Banyak bicara akan mendorong seseorang berpotensi membuat banyak kesalahan. Seperti diungkapkan AlGhazali, lidah memiliki duapuluh penyakit, seperti; berdusta, ghibah, namimah, kesaksian dan sumpah palsu, mencemooh, menghina, bicara tanpa faedah, dan lain-lain. Bahkan syaikh Abdul Ghani an Nabilisi menyatakan bahwa jumlah penyakit lidah mencapai tujuh puluh dua macam, dan dia telah membuat rinciannya secara lengkap.

Tentu saja hal yang demikian itu tidak dimaksudkan agar kita mengunci kedua bibir kita dari berbicara, namun sebaiknya kita membatasi diri dari berbicara yang berlebihan dan mencukupkan dengan pembicaraan yang bermanfaat saja. Cukuplah menjadi pelajaran buat kita betapa banyak manusia yang celaka hanya karena tergelincir dalam kata-kata dan pembicaraan yang tiada berguna dan membahayakan dirinya.

Diam yang lebih baik dari bicara adalah diamnya seseorang karena hendak menjaga diri dari bahayabahaya lisan. Al-Bukhari meriwayatkan sebuah hadits dalam kitab Shahihnya no. 6477 dan Muslim dalam kitab Shahihnya no. 2988 [3] dari Abu Hurairah bahwa Rasulullah bersabda.

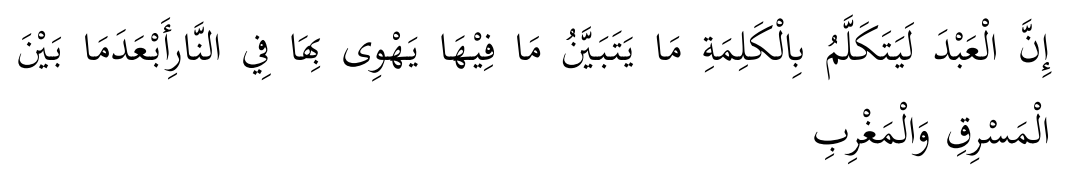


Setyoadi Purwanto : Memaknai Hadits Qul Khairan Auliyashmut dalam Konteks Pendidikan Islam di Era Revolusi Industri 4.0

Artinya:

"Sesungguhnya seorang hamba yang mengucapkan suatu perkataan yang tidak dipikirkan apa dampak-dampaknya akan membuatnya terjerumus ke dalam neraka yang dalamnya lebih jauh dari jarak timur dengan barat" (HR. Bukhari-Muslim)

c. Bicara baik senilai dengan sedekah

Hal ini sebagaimana hadits Nabi dari Adi bin Hatim r.a. ia berkata, Rasulullah saw. Bersabda: "Takutlah kalian terhadap api neraka, walaupun hanya dengan bersedekah sebagian biji kurma. Apabila tidak mendapatkannya cukup dengan berkata yang baik." (HR. Bukhari dan Muslim)

Secara tegas, dalam hadits lainnya Rasulullah menyebut setiap kalimat yang baik adalah sedekah, sebagaimana lafadz hadits berikut ini:

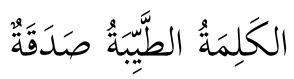

Artinya:

"Kalimat yang baik adalah sedekah" (HR Bukhori-Muslim, Lihat Shahiihul jaami' no. 4528).

Dan dikuatkan oleh hadits:

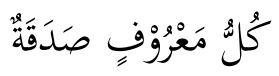

Artinya:

"Segala bentuk kebaikan bernilai sedekah." (HR. Muslim)

d. Makna qul khairan auliyashmut menurut para ulama

Imam Nawawi berkomentar tentang hadits ini ketika menjelaskan hadits-hadits Arba'in. Beliau menjelaskan, "Imam Syafi'i menjelaskan bahwa maksud hadits ini adalah apabila seseorang hendak berkata 
Setyoadi Purwanto : Memaknai Hadits Qul Khairan Auliyashmut dalam Konteks Pendidikan Islam di Era Revolusi Industri 4.0

hendaklah ia berpikir terlebih dahulu. Jika diperkirakan perkataannya tidak akan membawa mudharat, maka silahkan dia berbicara. Akan tetapi, jika diperkirakan perkataannya itu akan membawa mudharat atau ragu apakah membawa mudharat atau tidak, maka hendaknya dia tidak usah berbicara". Sebagian ulama berkata, "Seandainya kalian yang membelikan kertas untuk para malaikat yang mencatat amal kalian, niscaya kalian akan lebih banyak diam daripada berbicara".

Imam Abu Hatim Ibnu Hibban Al-Busti berkata dalam kitabnya Raudhah Al-'Uqala wa Nazhah AlFudhala, "Orang yang berakal selayaknya lebih banyak diam daripada bicara. Hal itu karena betapa banyak orang yang menyesal karena bicara, dan sedikit yang menyesal karena diam. Orang yang paling celaka dan paling besar mendapat bagian musibah adalah orang yang lisannya senantiasa berbicara, sedangkan pikirannya tidak mau jalan".

Beliau berkata pula, "Orang yang berakal seharusnya lebih banyak mempergunakan kedua telinganya daripada mulutnya. Dia perlu menyadari bahwa dia diberi telinga dua buah, sedangkan diberi mulut hanya satu adalah supaya dia lebih banyak mendengar daripada berbicara. Seringkali orang menyesal di kemudian hari karena perkataan yang diucapkannya, sementara diamnya tidak akan pernah membawa penyesalan. Dan menarik diri dari perkataan yang belum diucapkan adalah lebih mudah dari pada menarik perkataan yang telah terlanjur diucapkan. Hal itu karena biasanya apabila seseorang tengah berbicara maka 
Setyoadi Purwanto : Memaknai Hadits Qul Khairan Auliyashmut dalam Konteks Pendidikan Islam di Era Revolusi Industri 4.0

perkataan-perkataannya akan menguasai dirinya. Sebaliknya, bila tidak sedang berbicara maka dia akan mampu mengontrol perkataan-perkataannya.

Ditambahkannya, "Lisan seorang yang berakal berada di bawah kendali hatinya. Ketika dia hendak berbicara, maka dia akan bertanya terlebih dahulu kepada hatinya. Apabila perkataan tersebut bermanfaat bagi dirinya, maka dia akan bebicara, tetapi apabila tidak bermanfaat, maka dia akan diam. Adapun orang yang bodoh, hatinya berada di bawah kendali lisannya. Dia akan berbicara apa saja yang ingin diucapkan oleh lisannya. Seseorang yang tidak bisa menjaga lidahnya berarti tidak paham terhadap agamanya”.

Hajar menjelaskan, "Ini adalah sebuah ucapan ringkas yang padat makna; semua perkataan bisa berupa kebaikan, keburukan, atau salah satu di antara keduanya. Perkataan baik (boleh jadi) tergolong perkataan yang wajib atau sunnah untuk diucapkan. Karenanya, perkataan itu boleh diungkapkan sesuai dengan isinya. Segala perkataan yang berorientasi kepadanya (kepada hal wajib atau sunnah) termasuk dalam kategori perkataan baik. (Perkataan) yang tidak termasuk dalam kategori tersebut berarti tergolong perkataan jelek atau yang mengarah kepada kejelekan. Oleh karena itu, orang yang terseret masuk dalam lubangnya (perkataan jelek atau yang mengarah kepada kejelekan) hendaklah diam.” (lihat Al-Fath, 10:446)

e. Berkata yang baik lebih utama dari pada diam

Dalam hadits yang diriwayatkan oleh Imam Bukhari dan Imam Muslim tersebut diatas, Rasululah 
Setyoadi Purwanto : Memaknai Hadits Qul Khairan Auliyashmut dalam Konteks Pendidikan Islam di Era Revolusi Industri 4.0

menyebutkan berkata yang baik lebih dahulu dari pada kata diam. Para ulama, diantaranya Syaikh Utsaimin, dalam Kitab Syarah Arbain Nawawiyah mengatakan bahwa berbicara yang baik lebih utama daripada diam. Ketahuilah kalau yang dibicarakan itu baik maka ada beberapa manfaat:

Pertama: Bagi yang berbicara mendapat manfaat karena telah menyampaikan ucapan ucapan yang baik. Kedua: Bagi yang mendengar, dia telah menerima ucapan ucapan yang baik, bisa berupa nasehat, tambahan ilmu dan yang lainnya. Ini juga bermanfaat. Ketiga: Kalau diam hanya ada satu manfaat yaitu bagi yang tidak berbicara, karena dengan diam bisa lebih selamat.

Al Hafidz Ibnu Rajab Rahimahullah berkata: Dalam hadits ini Rasulullah memerintahkan untuk berkata yang baik dan tidak berbicara selainnya. Ini menunjukan bahwa tidak ada disana suatu perkataan yang seimbang dari segi perintah untuk mengucapkannya atau diam darinya, bahkan ada kalanya berupa kebaikan yang diperintahkan untuk diucapkan, dan ada kalanya bukan suatu kebaikan sehingga diperintahkan untuk diam darinya.

Maka tidaklah perkataan itu untuk selalu diucapkan, dan tidak pula diperintahkan untuk selalu diam. Tetapi wajib berkata yang baik dan diam dari perkataan yang jelek. Ulama' salaf banyak memuji sikap diam dari ucapan yang jelek, dan dari perkataan yang tidak perlu. Karena sikap diam itu sangat berat bagi jiwa. Sehingga banyak manusia yang tak mampu mengekang dirinya. Oleh karena itu 'ulama salaf berusaha mengekang 
Setyoadi Purwanto : Memaknai Hadits Qul Khairan Auliyashmut dalam Konteks Pendidikan Islam di Era Revolusi Industri 4.0

diri-diri mereka, dan bersungguh-sungguh untuk diam dari bicara yang tidak perlu.

4. Makna Perkataan yang Baik dalam Perspektif Ilmu Komunikasi

a. Komunikasi efektif perspektif barat

Hakekat komunikasi adalah proses penyampaian pesan dalam bentuk ide, pikiran maupun perasaan dari komunikator kepada komunikan. Komunikasi bisa dilakukan dalam berbagai kondisi secara lisan, tertulis, tatap muka, maupun melalui media tertentu. Aspek terpenting dalam sebuah proses komunikasi bukan saja tersampaikannya pesan dari komunikator kepada komunikan, namun lebih pada sejauh mana komunikasi berlangsung secara efektif.

Dalam pendekatan komunikasi, perkataan yang baik yang dikategorikan dalam komunikasi efektif mestilah ditinjau setidaknya dari empat unsur penting, yakni ; komunikator, pesan, media penyampai pesan, komunikan dan efek komunikasi. Hal penting yang menentukan kualitas komunikator adalah expertise (keahlian) dan trusworthiness (dapat dipercaya). Kombinasi dari keduanya akan membangun karakter seorang komunikator yang credible.

Selain unsur komunikator, Schram menyebut The Condition of Success in Communication yakni unsur pengelolaan pesan sebagai unsur penting sukses komunikasi lainnya. Selanjutnya ia merumuskan kondisi itu sebagai berikut: 
Setyoadi Purwanto : Memaknai Hadits Qul Khairan Auliyashmut dalam Konteks Pendidikan Islam di Era Revolusi Industri 4.0

1) Pesan harus dirancang dan dikomunikasikan sedemikian rupa untuk menarik perhatian komunikan.

2) Pesan harus dibuat menggunakan lambang/simbol yang dipahami komunikator dan komunikan.

3) Pesan harus menyentuh minat dan kebutuhan komunikan.

4) Pesan harus dibangun untuk memberi solusi atas minat dan kebutuhan informasi komunikan.

Selain komunikator dan pesan, media menjadi unsur penunjang tercapainya komunikasi efektif. Di era teknologi informasi saat ini peran media dalam komunikasi menjadi sangat vital, namun sebuah media akan sia-sia keberadaannya bila tidak digunakan komunikan dalam berkomunikasi. Oleh karenanya efektivitas media sangat ditentukan salah satunya oleh karekteristik komunikan. Para pakar menyampaikan apa yang mereka sebut sebagai "know your audience", yakni pengetahuan terhadap khalayak berkaitan dengan beberapa aspek seperti; waktu yang tepat, bahasa yang dimengerti, sikap dan nilai yang sesuai dengan komunikan, serta jenis kelompok dimana komunikasi akan dilaksanakan.

Unsur lain yang menunjang sebuah komunikasi efektif adalah efek atau dampak komunikasi itu sendiri. Efek komunikasi dapat dilihat pada saat komunikasi sedang berlangsung (dampak langsung), maupun setelah komunikasi usai (dampak tertunda). Dampak langsung komunikasi terlihat dari respon dan antusiasme komunikan dalam proses komunikasi, sementera untuk 
Setyoadi Purwanto : Memaknai Hadits Qul Khairan Auliyashmut dalam Konteks Pendidikan Islam di Era Revolusi Industri 4.0

menilai dampak tertunda sebuah komunikasi diperlukan sebuah instrumen data seperti angket, ceklist, dan lembar pedoman wawancara. Hasil respon komunikan yang terkumpul kenudian akan digunakan sebagai bahan evaluasi menyusun desain komunikasi selanjutnya.

b. Komunikasi efektif perspektif Islam

Mafri Amir dalam Etika Komunikasi Masa menggambarkan komunikasi efektif dalam perspektif Islam adalah komunikasi dan pembicaraan yang bersumber dari Al Quran. Menurutnya prinsip komunikasi dalam perspektif Islam itu adalah Qoulan sadiida, Qoulan Layyina, Qoulan Ma'ruufa, Qoulan Kariima, Qoulan Baliigha dan Qoulan Maisuura, sebagaimana telah diuraikan dibagian awal makalah ini.

\begin{tabular}{|c|l|l|}
\hline NO & ISTILAH QURAN & \multicolumn{1}{|c|}{ PENGERTIAN } \\
\hline 1 & Qoulan Sadiidan & $\begin{array}{l}\text { Perkataan yang benar, jujur, } \\
\text { mengena tepat pada sasaran }\end{array}$ \\
\hline 2 & Qoulan Layyiina & $\begin{array}{l}\text { Perkataan yang lemah- } \\
\text { lembut dan menyentuh hati }\end{array}$ \\
\hline 3 & Qoulan Ma'ruufa & $\begin{array}{l}\text { Perkataan yang baik dan } \\
\text { diterima oleh nilai-nilai yang } \\
\text { berlaku dalam masyarakat }\end{array}$ \\
\hline 5 & Qoulan Kariima & $\begin{array}{l}\text { Ucapan yang lembut berisi } \\
\text { pemuliaan, penghargaan, } \\
\text { pengagungan, dan } \\
\text { penghormatan tanpa celaan }\end{array}$ \\
\hline 6 & Qoulan Maisuura & $\begin{array}{l}\text { Perkataan fasih dan tepat } \\
\text { yang disertai cara } \\
\text { pengungkapan yang } \\
\text { mengesankan pendengarnya }\end{array}$ \\
\hline $\begin{array}{l}\text { Perkataan yang } \\
\text { menyenangkan, ringan, } \\
\text { mudah dipahami dan } \\
\text { mendekatkan diri } \\
\text { (membangun kedekatan) }\end{array}$ \\
\hline
\end{tabular}


Setyoadi Purwanto : Memaknai Hadits Qul Khairan Auliyashmut dalam Konteks Pendidikan Islam di Era Revolusi Industri 4.0

Selain beberapa prinsip yang bersumber dari Al Quran, komunikasi dalam perspektif Islam juga dapat kita simpulkan dari beberapa hadits Nabi dan pendapat ulama yang telah pula dibahas di bagian awal makalah ini.

\begin{tabular}{|l|l|l|}
\hline \multicolumn{3}{|c|}{ PRINSIP KOMUNIKASI NABI } \\
\hline Prinsip 1 & $\begin{array}{l}\text { Bicara yang baik adalah } \\
\text { ciri-karakter seorang } \\
\text { Muslim }\end{array}$ & $\begin{array}{l}\text { Hadits } \\
\text { Abdullah bin } \\
\text { Amr }\end{array}$ \\
\hline Prinsip 2 & $\begin{array}{l}\text { Bicara yang baik } \\
\text { membawa } \\
\text { keberuntungan, dan } \\
\\
\\
\text { diam (dari kata sia-sia) } \\
\text { membawa keselamatan. }\end{array}$ & $\begin{array}{l}\text { Hadits Ibnu } \\
\text { Mubarak }\end{array}$ \\
\hline Prinsip 3 & $\begin{array}{l}\text { Perkataan yang baik } \\
\text { bernilai sedekah }\end{array}$ & $\begin{array}{l}\text { Hadits Adi bin } \\
\text { Hatim }\end{array}$ \\
\hline
\end{tabular}

\begin{tabular}{|c|l|l|}
\hline NO & \multicolumn{1}{|c|}{ ULAMA } & \multicolumn{1}{|c|}{$\begin{array}{c}\text { PENDAPAT TENTANG } \\
\text { KATA YANG BAIK }\end{array}$} \\
\hline 1 & Syaikh Utsaimin & $\begin{array}{l}\text { Bicara yang baik lebih } \\
\text { utama daripada diam }\end{array}$ \\
\hline 2 & $\begin{array}{l}\text { Abu Hatim Ibnu } \\
\text { Hibban }\end{array}$ & $\begin{array}{l}\text { Orang bijak kata-katanya } \\
\text { berada dibawah kendali } \\
\text { hatinya, sementara orang } \\
\text { jahil hatinya dibawah } \\
\text { kendali lisannya }\end{array}$ \\
\hline 3 & Ibnu Hajar & $\begin{array}{l}\text { Boleh bicara dalam hal } \\
\text { yang diwajibkan dan } \\
\text { disunahkan, untuk yang } \\
\text { selainnya sebaiknya } \\
\text { banyak diam }\end{array}$ \\
\hline 4 & Imam Nawawi & $\begin{array}{l}\text { Menimbang \& fikirkan } \\
\text { dulu manfaat- } \\
\text { madharatnya }\end{array}$ \\
\hline 5 & Alhafidz Ibnu Rajab & $\begin{array}{l}\text { Berkata baik tak memiliki } \\
\text { pembanding yang setara } \\
\text { selainnya, maka jika tidak } \\
\text { lebih baik diam }\end{array}$ \\
\hline
\end{tabular}


Setyoadi Purwanto : Memaknai Hadits Qul Khairan Auliyashmut dalam Konteks Pendidikan Islam di Era Revolusi Industri 4.0

5. Makna Qul Khairan Auliyashmut dalam Konteks Pendidikan Islam di Era Revolusi Industri

Kualitas sebuah proses pembelajaran dipengaruhi oleh efektif tidaknya komunikasi yang terjadi di dalamnya. Komunikasi efektif dalam pembelajaran merupakan proses transformasi pesan berupa ilmu pengetahuan dan teknologi dari pendidik kepada peserta didik, dimana peserta didik mampu memahami maksud pesan sesuai dengan tujuan yang telah ditentukan, sehingga menambah wawasan keilmuan serta menimbulkan perubahan tingkah laku yang lebih baik.

Dalam konteks Pendidikan islam, pembelajaran haruslah dipandang secara utuh dan kompreshensif. Bukan saja aktivitas tatap muka di dalam kelas, namun juga seluruh interaksi dan komunikasi antara pendidik dan peserta didik. Hal itu berarti setiap interaksi-komunikasi pendidik dan peserta didik, di dalam maupun di luar kelas, haruslah dilihat sebagai sebuah proses pembelajaran yang diarahkan pada visi membangun manusia cerdas berakhlaq mulia.

Hadits Qul khairan auliyashmut dalam kontek Pendidikan islam bukan berarti Guru hanya boleh bicara seperlunya yang berhubungan dengan tema dan tujuan pembelajaran, selebihnya diam lebih baik. Tentu saja bukan demikian adanya. Pada dasarnya hadits ini memerintahkan kita untuk berbicara, bukan diam. Sekali lagi lafadz "auliyashmut" dalam hadits tersebut bukan bermakna perintah diam, namun diam adalah pilihan akhir jika tak ada lagi perkataan baik yang bisa diucapkan. Bobby Deporter dalam bukunya Quantum Learning sebagaimana dikutip 
Setyoadi Purwanto : Memaknai Hadits Qul Khairan Auliyashmut dalam Konteks Pendidikan Islam di Era Revolusi Industri 4.0

Irawati Istadi memaparkan data penelitiannya, dimasa awal pertumbuhannya anak-anak telah menerima 460 kata-kata komentar negatif dan hanya 75 komentar positif setiap harinya. Tentu saja pesannya bukan saja kita harus menghentikan kata-kata negatif dalam mendampingi anakanak, tetapi yang lebih ditekankan adalah kita harus memperbanyak kata-kata positifnya.

Arief Rachman pakar pendidikan menyampaikan dalam beberapa kesempatan, "Wahai Guru ngobrollah dengan murid-murid anda, wahai orangtua ngobrollah dengan anakanak anda!" Arif Rahman menekankan pentingnya ngobrol (bicara santai tentang apa saja yang mendukung visi pendidikan) untuk membangun interaksi dan saling percaya antara pendidik dan peserta didik, serta orangtua dan anak. Mengatakan kebaikan (dimensi aktif) wajib dilakukan dalam konteks Pendidikan Islam dalam membangun generasi, sementara diam (dimensi pasif) akan tetap memberi manfaat bila ia dimaksudkan menghindarkan diri dari kesia-siaan.

Dalam kontek era Revolusi Industri 4.0 yang serba digital, bahkan pembicaraan kini pun lebih banyak dilakukan secara pesan digital daripada lisan, maka makna komunikasi positif yang disebut 'ngobrol' oleh Arief Rahman tentu mengalami pergeseran pula. Sifat dan karakter manusia era revolusi industri yang semakin individualis mendorong mereka lebih nyaman berkomunikasi tertulis secara digital baik melalui computer maupun gawai berbasis internet. Kecepatan penyebaran pesan yang terjadi pun jauh lebih cepat dan luas dibandingkan dengan dialog verbal sacara lisan. Budaya copy paste di media social terkadang tanpa 
Setyoadi Purwanto : Memaknai Hadits Qul Khairan Auliyashmut dalam Konteks Pendidikan Islam di Era Revolusi Industri 4.0

menyeleksi kebenaran sumber informasi menjadi kebiasaan yang semakin dilazimkan.

Bila dikonstruksikan dari pandangan Abdulllah Nashih Ulwan maka 'mengatakan kebaikan' bisa dimaknai segala upaya pendidikan seperti mendidik dengan keteladanan, mendidik dengan pembiasaan, mendidik dengan nasihat, mendidik dengan perhatian dan mendidik dengan hukuman. Maka secara filosofis qul khairan 'mengatakan kebaikan' tidak saja dimaknai secara sempit mengucapkan kata-kata yang baik secara lisan, tetapi ia bisa mencakup tiga dimensi sekaligus:

a. Mengatakan dengan tindakan (teladan \& kebiasaan)

b. Mengatakan dengan lisan (nasehat $\&$ pelajaran)

c. Mengatakan dengan sikap (pengawasan \& hukuman)

Dan ketiga dimensi bicara kebaikan (Qul Khairan) tersebut diekspresikan dalam dua bentuk, yakni: pesan lisan secara tatap muka langsung dan pesan tertulis secara digital berbasis internet.

\section{KESIMPULAN}

Dari pembahasan di atas, pemaknaan hadits Qul khairan auliyashmut dalam konteks Pendidikan islam haruslah dilihat secara utuh dan komprehensif, sehingga implementasinya akan berdampak positif dan signifikan dalam mewujudkan tujuan Pendidikan Islam. Qul khairan dalam berbagai aspeknya perlu didesain secara matang dan terencana baik dalam pengembangan konten materi kurikulum, metode pembelajaran yang efektif dan pemanfaatan media yang tepat.

Implementasi pemaknaan lafadz Qul khairan auliyashmut dalam konteks Pendidikan Islam di Era Revolusi Industri 4.0 
Setyoadi Purwanto : Memaknai Hadits Qul Khairan Auliyashmut dalam Konteks Pendidikan Islam di Era Revolusi Industri 4.0

meliputi komunikasi formal di ruang kelas atau jam pembelajaran, komunikasi non formal (di luar jam pembelajaran, kegiatan ekstra), serta komunikasi informal (bersifat kekeluargaan atau bersama anggota keluarga/orangtua). Ketiga saluran komunikasi pendidikan tersebut di Era Revolusi Industri 4.0 semakin beralih dari budaya lisan ke budaya tulis dan digital. Oleh karenanya, tantangan pendidikan Islam di era Revolusi Industri 4.0 ke depan harus disikapi dengan menyiapkan konten pendidikan secara digital tanpa mengabaikan etika moral dalam pemanfaatan media digital tersebut. Perkataan terbaik sebagaimana tersirat dalam hadits Nabi di atas tidak saja menjadikan komunikasi berjalan efektif dan efisien, namun juga benar dan kontruktif. 
Setyoadi Purwanto : Memaknai Hadits Qul Khairan Auliyashmut dalam Konteks Pendidikan Islam di Era Revolusi Industri 4.0

\section{DAFTAR PUSTAKA}

Abdullah Nashih Ulwan, Pendidikan Anak Dalam Islam, Surakarta: Insan Kamil, 2012

Ahmad Warson Munawwir, Kamus Al Munawir,Surabaya: Pustaka Progressif, 1994

Buya Hamka, Tafsir Al Azhar Juz 22, Surabaya: Pustaka Islam, 1983

Effendi, Onong Uchjana, Ilmu Komunikasi Teori dan Praktik, Bandung: Rosda Karya, 1990

Fauzil Adzim, Saat Berharga untuk anak Kita, Yogyakarta: Pro-U Media, 2009

Imam Nawawi, Terjemah Lengkap Riyadhus Shalihin, Perjalanan Menuju Taman Surga, Surabaya: Jabal, 2011

Imam az Zabidi, Ringkasan Shahih Al Bukhari, Bandung: Mizan, 1998

Irawati Istadi, Mendidik dengan Cinta, Jakarta: Pustaka Inti, 2008

Mafri Amir, Etika Komunikasi Masa dalam Pandangan Islam, Jakarta: Logos, 1999

Syaikh Shafiyyurrahman al-Mubarakfuri, Shabhih Tafsir Ibnu Katsir,Jilid 5, Bogor: Pustaka Ibnu Katsir, 2006

Yusuf Qardhawi, Bagaimana Memahami Hadis Nabi SAW, Bandung: Karisma, 1994

, Problematika Islam Masa Kini, Qardhawi Menjawab, Bandung: Trigenda Karya, 1996

Jalaludin Rakhmat, Psikologi Komunikasi, Bandung: Remaja Rosdakarya, 1996

Azwir B. Chaniago, Kewajiban Berkata yang Baik http://azwirbchaniago.blogspot.com/2014/11/berkatayang-baik.html 
Setyoadi Purwanto : Memaknai Hadits Qul Khairan Auliyashmut dalam Konteks Pendidikan Islam di Era Revolusi Industri 4.0

Heru Yulias, Menjaga Lisan, https://masbadar.com/wpcontent/uploads/2009/07/menjaga-lisan.pdf

Mitra Wahyuni, Pola Perlakuan Orang Tua dan Dampaknya Pada Perilaku Anak Usia Dini, portalgaruda.org/article.php?article=

17935\&val $=6303 \&$ title $=$ Pola\% 20 Perlakuan $\%$ 20Orang $\% 20$ Tua

\%20dan\%20Dampaknya\%20Pada\%20Perilaku\%20Anak\%20U sia\% 20Dini,

Rika Putri, Komunikasi Efektif dalam Pembelajaran, http://www.bppp-tegal.com/web/index.php/ artikel/185komunikasi-yang-efektif-dalam-pembelajaran,

https://almanhaj.or.id/4089-berkata-benar-jujur-dan-jangandusta-bohong.html

https:/ / almanhaj.or.id/3197-menjaga-lisan-agar-selalu-berbicara baik.html

https://haditsarbain.wordpress.com/2007/06/09/hadits-15berkata-yang-baik-atau-diam/

https://muslimah.or.id/5118-bicara-baik-atau-diam.html

https://news.detik.com/berita/2523366/kasus-dedeh-mirip-aniklulusan-itb-yang-bunuh-3-anak-karena-paranoid

https://orienputra.wordpress.com/2018/02/19/tafsir-surah-annisa-ayat-9-membangun-generasi/ didownload tanggal 4 Agustus 2018

https://www.programjodoh.com/hadits-ke-14-kalimat-yang-baikadalah-sedekah/ didownload tanggal 6 Agustus 2018 
Setyoadi Purwanto : Memaknai Hadits Qul Khairan Auliyashmut dalam Konteks Pendidikan Islam di Era Revolusi Industri 4.0 